\title{
The Use of EFL Authentic Materials: A Gender-Line University Teachers' Perspective
}

\author{
AbdulRahman Al Asmari \\ Dean PYP \& Director of English Language Center, Taif University, Taif, KSA \\ E-mail: abdulasmari@gmail.com \\ Malik Ajmal Gulzar (Corresponding author) \\ Supervisor of Curriculum Development and Research Unit, English \\ Language Center, Taif University, Taif, KSA \\ E-mail: agmsfa@gmail.com
}

Received: 12-09-2015

Published: 01-03-2016
Accepted: $15-12-2015$

doi:10.7575/aiac.ijalel.v.5n.2p. 128
Advance Access Published: January 2016

URL: http://dx.doi.org/10.7575/aiac.ijalel.v.5n.2p.128

\begin{abstract}
The present study attempted to explore the role of authentic materials (henceforth AM) in the interaction of the Saudi EFL university classrooms with an emphasis placed on gender-based analysis of EFL university teachers' classroom practices. Moreover, it introduces the concepts of what define AM, and presents various perceptions of researchers, teachers on their usefulness. To examine this phenomenon, Saudi EFL teachers' perceptions about the use of authentic materials were investigated to improve English language skills at Saudi EFL university classrooms. After employing a structured questionnaire, the results indicated that Saudi EFL university teachers authenticated the significance of AM for improving language skills of Saudi EFL university students. Also, the results reflected that Saudi EFL teachers showed their preferences for the use of balanced AM and English for Academic Purposes (EAP) textbooks. The findings elicited the meaningful implications for the use of AM especially for the Saudi EFL university students.
\end{abstract}

Keywords: Saudi EFL university teachers, beliefs, authentic materials, EAP books, EFL context

\section{Introduction}

English is taught as a foreign language in Saudi schools. Despite the fact that students study it as a subject over several years, English may not have many applications beyond school settings. English is neither the medium of instruction nor the official language at school levels in Saudi Arabia (AlHarbi, 2005). Several studies have revealed that the students do not have enough exposure to the English language, and as a result, their English language skills remain poor when they undertake undergraduate studies (Almulhim, 2001). Although, Saudi students enroll in tertiary education after studying English language for eight years, their standard of English proficiency remains very low (Gulzar \& Al Asmari, 2013a). To tackle this situation, Saudi universities implemented Preparatory Year Program (hereinafter PYP) to bridge the gap between the level of the secondary schools and the undergraduate university programs. Focusing on this dismal situation, Al-Seghayer (2011, p. 122) claims that "Arab learners find it difficult to communicate freely in the target language". This may be due to the methods of language teaching and the learning environment which may be unsuitable for learning a foreign language (FL) in the situation of Saudi Arabia (Gulzar, Gulnaz, \& Ijaz, 2014)

In order to deal with the students' low English language proficiency, one solution was that teachers, therefore, must simulate real-world situations in the classroom (Stern, 1981). And one way of exploiting this situation may be the best use of AM and examples of such materials include newspapers, magazines, TV programs, radio talks, menus, brochures, comics, novels, short stories, weather forecasts, and recipes (Hedge, 2000). A growing mass of research has reported that AM in the EFL classrooms are effective resources that can positively contribute to students' progress (e.g., Weyers, 1999; Breen, 1985; Lee, 1995; Herron \& Seay, 1991; Nostrand, 1989; Rogers \& Medley, 1988; Duquette, Dunnett, \& Papalia, 1987). Foreign language pedagogy is increasingly focusing on the functional use of language while instructors look for materials which more closely reflect the language that students will encounter outside the classroom. Therefore, EFL teachers' attitudes toward the use of authentic materials in their classes have been an issue that might not have received sufficient attention in the context of Saudi EFL classrooms. Consequently, it was immensely useful to generate equal line segments between male and female teachers to promote language skills at par amongst both genders (male and female students) of Saudi EFL university learners.

\subsection{Objectives of the study}

The objectives of the present research are:

i. To examine the perceptions of Saudi EFL university teachers [males \& females] towards the use of AM in PYP classrooms. 
ii. To find out the perceptions of EFL university teachers [males \& females] towards the significance of AM as EFL resource for Saudi PYP learners.

iii. To examine the utility of EAP textbooks amongst Saudi EFL teachers [males \& females] in PYP classrooms of Saudi universities.

\subsection{Operational definitions of authentic materials}

Adams (1995, p. 4) defines authentic materials as "Any material which has not been specifically produced for the purposes of language teaching". Guariento and Morley (2001, p. 347) define an authentic material as "an authentic text... created to fulfill some social purpose in the language community in which it was produced". Also, the term 'authentic' was used "to refer to language samples that reflect a naturalness of form and an appropriateness of cultural and situational context that would be found in the language as used by the native speakers" (Rogers \& Medley, 1988, p. 468). In a similar sense, Lee (1995, p. 324) describes that "a text is usually regarded as textually authentic if it is not written for teaching purposes, but for a real life communicative purpose, where the writer has a certain message to pass on to the reader".

\section{Review of the previous studies}

Many empirical studies have been conducted to examine the significance of the AM and the results revealed the positive impact on learners who were exposed to authentic texts. For example, Miller (2005) and Thanajaro (2000) proved that aural language of the students was improved with the incorporating of AM. They confirmed that students' listening comprehension increased with the exposure of AM on four adult students of American universities. Similarly, the study of Young (1999) reported better scores with the use of AM in comparison with the use of textbooks only while investigating the effectiveness of AM amongst the Spanish learning students at university level. Similar results have also substantiated the use of authentic texts focusing on the improvement of reading skills (Carney \& Franciuli, 1992). Moreover, Gilmore (2007) made the comparison of the effectiveness of AM with textbook materials to investigate the learners' communicative competence in a Japanese university. The presented statistical results of the study showed significant improvements in the experimental group than the controlled group in six out of eight tests designed to measure different types of competence. Chaves $(1998$, p. 111) also concluded that "the authentic input allowed learners to focus on a wider range of materials and it had beneficial effects on the learners' development of communicative competence".

The impact of AM was further elaborated by giving a solid logic as students usually have trouble understanding texts outside of the classroom because classroom reading materials do not reflect the language of the real world (Ur, 1996). It has also been asserted that authentic reading materials should remain a critical component of language programs (Berardo, 2006). In this regard, Hadley (2001, p. 97) concluded that the

"Use of real or simulated travel documents, hotel registration forms, biographical data sheets, train and plane schedules, authentic restaurant menus, labels, signs, newspapers, and magazines will acquaint students more directly with real language than any set of contrived classroom materials used alone".

Therefore, it sounds sensible to base students' learning on a variety of AM to give them exposure to different texts for different purposes. While giving an examination to the students studying German as a FL, Bernhardt and Berkemeyer (1988) found out that all levels of students were able to manage using authentic texts. Similarly, Chaves (1998) examined 1,500 high school students' abilities to read AM after one to five years of FL instruction at three different levels of language difficulty. The researcher found that all the participants were able to deal with all of the authentic texts they were asked to read even at the beginning level. The above-mentioned reviews of different studies conducted in different contexts have demonstrated the effectiveness of AM in many ways. The use of AM expose students to the language that is used in the real world to enhance their language skills and upgrade their stylistic choices at all levels (Gulzar \& Abdulrahman, 2013a).

\subsection{Statement of the problem}

At present, the main objective of teaching in EFL classrooms in Saudi Arabia is to prepare the students to get improvement in their English language skills as it is extremely important to succeed in higher academic life. (Gulzar, \& Abdulrahman 2013b). Focusing on the efforts of improving language skills, the present policies of KSA are signifying a growing recognition that delivery of English language is imperative from the beginning of the primary education. Furthermore, as there has not been any significant research done with a focus on AM as a strategic source, particularly in the context under study, the present study may contribute to the tactical guidance for the spread of AM as a teachingstrategic-source in the EFL classrooms at Saudi universities. Hence, the researchers expect that language research along these lines will be a growing area for practicing teachers and language curriculum designers. In-class use of AM does not seem to be a common practice in the Saudi EFL context, despite its significance that has been stressed in the previous studies conducted in other contexts (e.g., Otte, 2006; Miller, 2005; Thanajaro, 2000). Due to lack of research in this specific area, there is a growing need for more elaborative evidence in the form of gender-based EFL university teachers' viewpoints about the use of AM in the Saudi EFL university classrooms. Moreover, Saudi male and female EFL teachers' perceptions of AM are significant to identify the effects of AM on improving English language skills of Saudi EFL learners. This study may contribute to expand on the existing mass of research focusing on gender-based issues related to the use of AM and may also add to the efforts exerted to approach appropriate strategies of employing AM in EFL university context. 
The following research questions are posed in order to investigate the effectiveness of AM in the Saudi EFL university classrooms:

Q.1. What are the perceptions of EFL university teachers [males \& females] about the significance of EAP textbooks for Saudi PYP students?

Q.2. What are the perceptions of EFL university teachers [males \& females] towards the effectiveness of AM in the Saudi EFL university context?

\subsection{Study hypotheses}

This study has the following hypotheses:

H1. There are statistically gender-based differences in the perceptions of EFL teachers [males and females] towards the perceived effectiveness of EAP books in the Saudi universities EFL classrooms.

H2. There are statistically gender-based differences in the perceptions of EFL teachers [males and females] towards the perceived significance of AM in the Saudi universities EFL classrooms.

\section{Research design}

The design of the current study is quantitative in nature in which a 5-point Likert-scale ranging as 'strongly disagree, disagree, uncertain, agree, strongly agree' was developed as a measuring instrument. Survey questionnaire is a popular method of collecting data. The questionnaires were distributed among the participants to elicit their perceptions about the use of AM and EAP books in English language teaching/learning process in the context of Saudi EFL university classrooms. Crookes and Schmidt (1991, p. 51) described the following merits of the survey design: “....... generalizes about the entire population by collecting data from the small portion of that population. It reveals the characteristics of the communities and institutions in a relatively unbiased and scientifically rigorous manner". In spite of some negligible demerits, this method is thought to be the most commonly used technique to collect data in a quantitative paradigm.

\subsection{Instrumentation}

The final instrument had 13 items divided into the following two sub-categories: i. EFL university teachers' [males and females] perceptions towards the perceived effectiveness of EAP books in Saudi EFL university classrooms (6 items), ii. EFL university teachers' [males and females] perceptions towards the perceived significance of AM in Saudi universities EFL classrooms ( 7 items). The researchers managed to collect 137 questionnaires out of 150 . One hundred thirty seven questionnaires were completed in all forms in which 77 were received from EFL male teachers and 60 were received from EFL female teachers from the staff of Taif University English Language Centre (TUELC) during the academic year 2014.

\subsection{Statistical analysis}

The researchers run Independent-samples to generate descriptive statistics, namely the means, medians, standard deviations and percentages as well as to identify any significant differences in the perceptions of male and female participants of this study. The data generated through the distributed questionnaires were manually entered, coded and analyzed using SPSS aiming to answer the research questions of the present study and to test its hypotheses.

\subsection{Validity and reliability}

The questionnaire was initially administered to 20 EFL university teachers at TUELC. Their responses were coded and the reliability coefficient test was run for the instrument as a whole as well as for its two parts separately using SPSS version 16.0. The Cronbach Alpha value remained .8838 for the instrument as a whole, which is a highly acceptable consistency of reliability. Elhadi $(2008$, p. 10) defines that "a test is said to have face validity if it looks as if it measures what it is supposed to measure". The "reliability is the stability or consistency of the assessment" (Mangubhai, 2006, p. 53). To evaluate the reliability and the validity of the instrument, the researchers used Cronbach's Alpha Reliability Coefficient for Likert-type scale rule as mentioned below:

$$
R=\frac{N(\mathbf{S} D) 2-M(N-M)}{(\mathrm{N}-1) ! S \mathrm{D}) 2}(\text { Elhadi2008:101) }
$$

Where:

$\mathrm{R}=$ the whole instrument Reliability Coefficient.

$\mathrm{M}=$ the Mean of the Instrument.

$(\mathrm{S} . \mathrm{D})^{2}=$ the variance of the instrument. (Square of Standard Deviation)

$\mathrm{N}=$ the number of questions of the instrument.

When the researcher applied the rule above them:

$\mathrm{M}=3.2$

$(\mathrm{S} . \mathrm{D})^{2}=13.1$

$\mathrm{N}=13$ 
The researchers found out that the Alpha Coefficient was equal to 0.8560 (0.86 (proximally equal to 0.86 ). The researchers calculated the validity of using the following formula:

Validity coefficient $=\sqrt{\text { Reliabilitycoefficient }}$

So, Validity coefficient was $=\sqrt{0.86}=0.93$

Both the reliability and the validity coefficients were quite high which proved the validity of the instrument.

\section{Results and discussions}

The data generated through the questionnaire were analyzed thematically to answer the research questions and to examine the hypotheses of the current study. First, EFL university teachers' responses related to their perceptions of the effectiveness of EAP textbooks are presented and discussed. Afterwards, the part of the questionnaire which reports on the participants' responses about their views of the significance of the AM in Saudi EFL university classes are also laid out and discussed thoroughly.

\subsection{Effectiveness of EAP textbooks in Saudi universities}

Table 1. EFL university teachers' perceptions of the effectiveness of EAP textbooks in Saudi universities

$\begin{array}{lllllllll}\text { Questionnaire Items } & \text { Group } & \mathrm{n} & \mathrm{df} & \mathrm{T} & \mathrm{SD} & \mathrm{M}\end{array}$

Ranking

$1 \quad$ EAP textbooks are based on only artificially males $77 \quad 135 \quad-1.2526 \quad 2.5065 \quad 6$ developed materials.

\begin{tabular}{lrrrrrr} 
& \multicolumn{7}{c}{2.854} \\
females & 60 & 116.799 & - & 1.45167 & 3.1667 & 3
\end{tabular}

2 EAP textbooks incorporate materials taken from a $\quad$ males $\quad 77 \quad 135 \quad-\quad \begin{array}{lllll}7.07272 & 2.8182 & 3\end{array}$ real life of the native speakers.

\begin{tabular}{lrrrrrr}
\multicolumn{8}{c}{1.102} \\
\hline females & 60 & 118.994 & - & 1.20685 & 3.0333 & 4
\end{tabular}

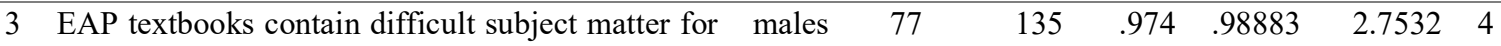

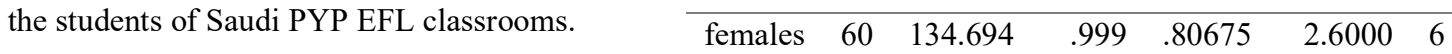

4 Students find it difficult to answer questions about $\quad$ males $\quad 77 \quad 135 \quad \begin{array}{lllll}7.35699 & 2.8831 & 2\end{array}$ the artificially developed material.

\begin{tabular}{lrrrrrr} 
& \multicolumn{7}{c}{1.411} \\
females & 60 & 131.812 & - & 1.23233 & 3.2000 & 2
\end{tabular}
EAP textbooks motivating.

$\begin{array}{lrrrrrr}\text { males } & 77 & 135 & - & .93683 & 2.5844 & 5 \\ \text { females } & 60 & 122.770 & - & .99943 & 2.8667 & 5\end{array}$

\begin{tabular}{|c|c|c|c|c|c|c|c|}
\hline \multirow{2}{*}{\multicolumn{2}{|c|}{$\begin{array}{r}6 \text { Students' interest can be enhanced with the help } \\
\text { of activities devised through materials other than } \\
\text { available in the EAP textbooks. }\end{array}$}} & \multicolumn{6}{|c|}{ 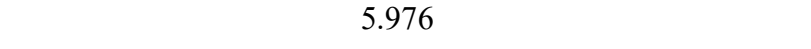 } \\
\hline & & \multicolumn{2}{|c|}{$\begin{array}{ll}\text { males } & 77 \\
\text { females } \quad 60\end{array}$} & 129.741 & $\begin{array}{r}- \\
6.308\end{array}$ & 69298 & 4.1667 \\
\hline
\end{tabular}

The respondents' given rankings identified for all the six variables in the part one of the questionnaire is presented in Table 1 above. The first item 'EAP textbooks are based on only artificially developed materials' was ranked by the female participants at No. 3 with a mean of 3.1667, while male respondents ranked it at No.6 with a mean ranking of 2.5065. Moreover, the highest standard deviation (SD hereinafter) 1.45167 for females reflects that the respondents were not in agreement with one another about the significance of this variable. On the other side, the second highest SD 1.2526 of male respondents also implies that the respondents were not in agreement with one another about the significance of this variable. The results show a wider gulf between the male and female teachers' viewpoint about this item and the same division is also reflected through SD. This may reflect that the participants of both genders were not certain about the effectiveness of artificially developed textbooks.

The second item 'EAP textbooks incorporate materials taken from a real life of the native speakers' was ranked by the male participants at No. 3 with a mean ranking of 2.8182, while the female respondents ranked it at No.4 with a mean ranking of 3.0333. The third highest SD 1.07272 for males reflects that the respondents were also not in agreement with one another about the significance of this variable. Conversely, the fourth highest SD 1.20685 of female 
respondents also reflects the same. It can be inferred from the present study results that the EAP textbooks are not based on AM to provide a real life situation. The results of this variable do not go in line with other empirical studies where the researchers have suggested that students' motivation and self-satisfaction increased after exposure to authentic texts (Otte, 2006; Thanajaro, 2000). Otte (2006) argues that AM make a major contribution to overcoming certain cultural barriers to language learning. Moreover, several previous studies have found that even beginning language learners can benefit from the use of AM in language instruction (Maxim, 2002; Bernhardt \& Berkemeyer, 1988). Similarly, Herron and Seay (1991), in a study conducted on intermediate-level students, found that students who listened to authentic radio tapes as a substitute for regular classroom activities demonstrated significantly higher listening comprehension than those students who were not exposed to authentic radio program.

The third variable 'EAP textbooks contain difficult subject matter for the students of Saudi PYP EFL classrooms' was ranked by the male participants at No. 4 with a mean ranking of 2.7532, while female respondents ranked it at No.6 with a mean ranking of 2.6000. Further, the second lowest SD for both male (. 98883) and female respondents (. 80675) implies that both respondents were not fully in disagreement while determining the significance of this variable. The results of this variable reveal that the EAP textbooks were not very difficult for the students of Saudi EFL university classrooms. The results of the current study at this point supported the findings of Bernhardt and Berkemeyer (1988) and Maxim (2002) who asserted that textbooks can build a wall between the students and the real language and may fail to respond to the students' needs and interests. Also, the difficulty level of EAP textbooks may be a reason due to which Saudi EFL university students show poor performance. Davison and Dowsin (1998) also authenticated the findings of the present study that textbooks cannot create interest among students for reading as they consist of fixed and monotonous reading materials.

The fourth variable 'students find it difficult to answer questions of different tasks for artificially developed materials' was identified as the second important variable by both male and female participants with a mean value of 2.8831 for males and 3.2000 for females respectively. In addition, the second highest SD 1.23233 for females and the highest SD 1.35699 by male respondents imply that the respondents were not in agreement with one another about the significance of this variable. The results of the current study may align with Hirsh and Nation (1992, p. 238) who claimed that "through a carefully organized and richly divergent variety of authentic materials, students can acquire the greater ability to develop cultural understanding by themselves". Moreover, Crossley, McCarthy, Louwerse, and McNamara (2007) investigated the differences in linguistic structures between simplified and authentic reading texts using computational tools. They found that simplified texts demonstrated more syntactic complexity than authentic texts do. Similarly, the findings of the present study reported that students found it difficult to answer the questions for artificially developed materials.

The fifth item 'the students in the Saudi EFL classrooms find EAP textbooks motivating' was identified as the fifth important variable by both male and female respondents with mean value ranking of 2.5844 for males and for 2.8667 for females respectively. The third highest SD.99943 allocated by females reflects that the respondents bear medium inter rater differences about the significance of this variable. On the other hand, the lowest SD.93683 of male respondents also implies the same. Variables 4 and 5 were ranked at No. 2 and No. 5 respectively by the respondents. Based on such emerging results, artificially developed materials seem to cause difficulty: a point that needs to be carefully considered by curriculum designers.

Variable 6 'students' interest can be enhanced with the help of activities devised through materials other than those available in the EAP textbooks' was identified as the most important item by the participants with a mean of 3.1948 for males and 4.1667 for females. As female respondents allocated the lowest SD.69298 for this item, this reflects that the female respondents bear greater similarity in their perceptions about the significance of this variable. The female respondents, however, allocated high SD to this variable (SD 1.10071) and ranked at No.4. This may imply that the respondents were not in agreement with one another about the significance of this variable. Data analysis also showed that both male and female respondents supported the use of AM to stimulate the interest of Saudi EFL university students.

Based on the above, it can be inferred from the results of part one of the questionnaire that EAP textbooks may not suffice the needs of the students for organizing a successful language learning program. Supporting the use of AM, Ghosn (2002) claims that authentic short stories effectively motivate students and promote the development of skills necessary for L2 academic literacy. Harmer (2001) suggests that, despite many textbooks' use of non-authentic materials to practice specific language points, only authentic materials will 'genuinely' improve listening and reading skills. Moreover, the findings of the current study reveal that the cohort of both sample groups emphasized that in order to understand the sequence of meaning embedded in the text, students need a broader understanding of cultural aspect and this can be achieved by exposing them to the authentic material. Both sample groups identified the significance of variables 4,5 , and 6 by providing them the same high ranking. Conversely, the participants' responses of both genders reflected differences while determining the effectiveness of EAP books and also unanimously raised some concerns about the utility of EAP textbooks. 
4.2 Significance of $A M$ in Saudi EFL university classes

Table 2. EFL university teachers' perceptions of the significance of AM in Saudi EFL university classroom.

\begin{tabular}{|c|c|c|c|c|c|c|c|}
\hline Questionnaire Items & Group & $\mathrm{n}$ & df & $\mathrm{T}$ & $\mathrm{SD}$ & M & Ranking \\
\hline \multirow{2}{*}{$\begin{array}{l}\text { Teachers must rely on authentic materials for } \\
\text { improving language skills in Saudi EFL } \\
\text { classrooms. }\end{array}$} & Males & 77 & 135 & -2.455 & 1.30395 & 3.3377 & 5 \\
\hline & Females & 60 & 134.818 & -2.543 & .97714 & 3.8333 & 3 \\
\hline \multirow{2}{*}{$\begin{array}{l}8 \text { AM help developing interest in language-learning } \\
\text { process of Saudi EFL students. }\end{array}$} & Males & 77 & 135 & -4.131 & 1.41167 & 3.1818 & 6 \\
\hline & Females & 60 & 127.174 & -4.384 & .84305 & 4.0333 & 1 \\
\hline \multirow{2}{*}{$\begin{array}{l}\text { 9. AM can particularly help improve basic skills of } \\
\text { EFL students of Saudi universities. }\end{array}$} & males & 77 & 135 & -3.538 & 1.33541 & 3.3506 & 4 \\
\hline & females & 60 & 124.465 & -3.773 & .75838 & 4.0333 & 1 \\
\hline \multirow{2}{*}{$\begin{array}{l}10 \text { AM can also be used to nurture the language } \\
\text { learning habits amongst the Saudi EFL university } \\
\text { students. }\end{array}$} & males & 77 & 135 & -2.138 & 1.22934 & 3.4286 & 2 \\
\hline & females & 60 & 134.608 & -2.219 & .90510 & 3.8333 & 3 \\
\hline \multirow{2}{*}{$\begin{array}{l}11 \text { Activities are devised on the excerpts taken from } \\
\text { the AM for improving reading \& writing skills in } \\
\text { the Saudi EFL classrooms. }\end{array}$} & males & 77 & 135 & -3.486 & 1.01543 & 3.0909 & 7 \\
\hline & females & 60 & 127.053 & -3.487 & 1.01347 & 3.7000 & 4 \\
\hline \multirow{2}{*}{$\begin{array}{l}12 \text { AM is the best tool that can play an effective role } \\
\text { to motivate students. }\end{array}$} & males & 77 & 135 & -2.943 & 1.17998 & 3.3636 & 3 \\
\hline & females & 60 & 134.733 & -3.051 & .87721 & 3.9000 & 2 \\
\hline \multirow{2}{*}{$\begin{array}{l}13 \text { English Newspapers, magazines and children's } \\
\text { magazines should be preferred as supporting } \\
\text { materials to teach language skills. }\end{array}$} & & 77 & 135 & -2.952 & 1.36252 & 3.4545 & 1 \\
\hline & & 60 & 123.333 & -3.153 & 75838 & 4.0333 & 1 \\
\hline
\end{tabular}

Data analysis of part two of the questionnaire is presented in Table 2 above. Variable seven 'teachers must rely on authentic materials for improving language skills in Saudi EFL classrooms' was ranked by the female participants at No. 3 with a mean ranking of 3.8333, and male respondents ranked it at No.5 with a mean ranking of 3.3377 . Moreover, the second high SD.97714 for females reflects that the respondents were not in agreement with one another about the significance of this variable. On the other hand, the fourth highest SD 1.30395 implies that the male respondents had higher differences with one another about the significance of this variable. As such, the results of this variable demonstrated the desperate opinion of male and female teachers' viewpoints and the same discrepancy was further reflected through SD. In other words, the present study participants were not certain about the implication of relying on AM for the development of language skills. Fanselow and Crymes (1976, p. 164) while defining the complications of using AM replicating the results of the present study and suggested that teachers ought to guide learners via pedagogical involvement. For example, if students were expected to write comprehension questions on a weather report without any guidance, they may not have ample knowledge of the code to produce anything and this may put them in a perplexing situation. This is one of the major criticisms on the use of AM in EFL classrooms, and the results of the variable seven of the current study also support these assumptions.

Variable eight 'AM help developing interest in language-learning process of Saudi EFL students', was ranked at No. 6 with a mean of 3.1818 by male participants and female respondents ranked it at No.1 with a mean of 4.0333 . In this regard, the third highest SD 1.41167 for males may convey that the respondents held different viewpoints about the significance of this variable. However, the second highest SD.84305 of female respondents may imply that female respondents were not fully in disagreement with one another about the significance of this variable. Both the sample groups were at diametrically opposed each other while reporting the significance of this variable. Data analysis of the second part of the questionnaire reflected that due to this perplexing situation, the use of AM could not be employed properly in Saudi EFL university classrooms. In alignment with the present study results, Fanselow and Crymes, (1976) and Day and Bamford (1998) rightly figured-out this situation and claimed that no criterion has been identified to justify the use AM, and there is no clear consensus on the actual benefits to learners. Keeping in view the divided view point amongst the participants, another study may be recommended getting further insights about the use of AM in EFL classes.

The ninth variable 'AM can particularly help improve basic skills of EFL students of Saudi universities' was ranked by the male participants at No. 4 with a mean ranking of 3.3506, while female respondents also ranked it at No.1 with a mean ranking of 4.0333. Moreover, the lowest SD.75838 of female respondents implies that female respondents were having a lesser disagreement with one another about the significance of this variable, and it showed firmness amongst female respondents about the significance of this variable. The second highest SD 1.33541 for males reflects that they held disparate viewpoints about the significance of this variable. Data analysis of variable nine may signify that both sample groups considered the significance of the AM for the improvement of Saudi EFL students, but their understanding level of this significance was quite different.

The tenth variable 'AM can also be used to nurture the language learning habits amongst the Saudi EFL university students' was identified as the second important variable by the male participants with a mean of 3.4286, and the female 
respondents also ranked it at No.3 with a mean of 3.8333. In addition, the fourth highest SD.90510 of female respondents implies that the respondents were not in agreement with one another about the significance of this variable. On the other side, the third highest SD 1.22934 by males reflects the same. Such results were reported by several assumptions in the previous studies, e.g. Miller, (2005) and Bacon, (1989) were in favor of the use of AM, and they suggested that an early exposure to such texts would help students develop a useful mechanism of comprehension even with more technical and complex passages. Also, in the current study both male and female participants supported the use of AM to help-out the Saudi EFL university students.

Data analysis showed that the eleventh variable 'activities are devised on the excerpts taken from the AM for improving reading \& writing skills in the Saudi EFL classrooms' was identified as the seventh important variable by the male participants with a mean of 3.0909, and the female respondents ranked it at No.4 with a mean of 3.7000. With that in mind, the lowest SD was 1.01543 by males and 1.01347 by female respondents implying that the respondents bear reasonable agreement with one another while ranking the significance of this variable. It was quite alarming that the present study results reflected that male respondents were not using AM at the maximum level to improve the language skills of the Saudi students. Conversely, female respondents reflected more tilts towards using AM for improving the language skills of the students,. Such gender-based discrepancy in viewpoints may clearly be observed throughout the present analysis of the second part of the questionnaire.

Variable twelve 'AM is the best tool that can play an effective role to motivate students' was ranked at No. 3 by the male respondents with a mean ranking of 3.3636 and it was ranked at No.2 position by females. The relatively lower SD.87721 by female respondents reflects an agreement amongst female participants about the significance of this variable. As for males, the second highest SD 1.17998 reflects their wider disagreement on the significance of this variable. The results of this variable showed a great concurrence with the belief of Day \& Bamford (2008) and Gilmore (2007) who claimed that authentic materials are a motivating force for learners. Supporting the use of AM, Maxim (2002) also argues that AM can work in conjunction with EAP textbooks to enhance learners' development, and the use of authentic texts is now considered to be one way of increasing students' motivation for learning since they give the learner the feeling that he or she is learning the real target language as it is used by the community that speaks it. The preferences of the present study respondents revealed that the use of AM kindle the interest of the students and help improve language skills for the students at all levels. The beliefs of the EFL university teachers as emerged while sequencing the findings of the current study coincide with the beliefs reported by Hedge (2000). Herron and Seay (1991) also supported the use of AM for teaching language skills. Therefore the findings of the present study may convey that teachers were fully aware of the utility of the AM as supporting materials to enhance the language competence of the Saudi EFL university students.

Variable thirteen 'English Newspapers, magazines and children's magazines should be preferred as supporting materials to teach language skills' was ranked at No. 1 by the male respondents with a mean of 3.4545 while it was ranked at No.1 position too by female participants with a mean of 4.0333 . Further, the lowest SD .75838 of female respondents highlights that the female respondents were in agreement with one another as compared to the male respondents about the significance of this variable. On the other side, the highest SD 1.36252 for this variable compared to other variables indicated a low consensus amongst male respondents about the significance of this variable. It might be an important finding that both genders stress the importance of AM, and highlighted some problems caused by the use of EAP textbooks. This result goes in line with a suggestion presented by Young $(1999$, p. 145) who stated that "items from newspapers, popular, or professional magazines can be introduced over a period of time for intensive and extensive reading practice". For EFL learners, even a single page of a newspaper provides sufficient practice for extensive and intensive reading in the classroom. Focusing on these materials, EFL university teachers may help students by reducing monotony and boredom and then they can direct the students towards the given tasks. Based on the present study results, it can be suggested that the respondents were split in their perceptions towards various questionnaire items. Moreover, significant differences were found in the opinion of male and female respondents about the variables collated in the cluster of the second part of the questionnaire. However, the utility of AM is not denied; rather, AM was considered significant to enable students to overcome their language deficiencies.

\section{Conclusion}

The present study aimed at investigating the role of AM in the Saudi EFL university classrooms. The results of the present study indicated that both sample groups (i.e. male and female EFL Saudi university teachers) showed differences in their perceptions on several items. The values assigned by male respondents suggested more consensus on the use of AM in Saudi EFL classrooms as it was reflected on the low value of SD by agreeing on four variables (4, 5,6 , and 13) out of 13 items. On the other hand, females reflected low consensus and provided divided views on the variables such as, 2, 3, 7, 8, 9, and 10 by assigning comparatively higher SD values to these items. Both male and female EFL university teachers' perceptions about the use of the AM were not on the same line. This dichotomy may provide wider differences about the thematic use of AM, and it may be due to the unavailability of any set parameters concerning the utilization of AM in the Saudi EFL classrooms. The quantitative analysis of the study also confirmed that the both sample groups represented by the cohort of this study provided incongruent views on the significance of AM in teaching Saudi EFL university classrooms. These widely divergent opinions about the use AM may be one of the reasons for the negligence of employing AM in Saudi EFL university classrooms. As a result, lesser opportunities are offered to help students with their poor performance of learning language skills. Thus, the proper implementation of AM in Saudi EFL university classrooms may help students get the exposure of a real life discourse that occurs in the 
natural interaction outside the classroom. Also, the teachers in the current study recommended the use of AM as an authentic-strategic-source and especially in conjunctions with EAP textbooks for the improvement of language skills of Saudi EFL students. From another perspective, the findings of the current study revealed that a limited scope of materials regarding authenticity of the prescribed textbooks is one of the main impediments to students to get improvement in language skills. Moreover, both male and female teachers need to develop resolute understanding about using multifaceted benefits of AM to teach English in Saudi EFL university classrooms. It can be claimed since findings reflect that the use of AM in the Saudi EFL university classrooms can bring the major changes in the academic atmosphere for the development of language skills. However, it is obvious that the level of success and achievement in specific areas may vary extensively and can be affected by many different factors. For instance, the nature of activities based on AM, learners' own contributions, and the real-life-like classroom situation are constituent elements that need to be considered while devising lesson plans for the Saudi EFL classrooms. All in all, it can be concluded that the findings of the present study may help teachers to re-set classroom dynamics by exploiting AM as a strategic-source to produce a greater number of opportunities for the Saudi EFL university students. To initiate collaborative and coordinative teaching in the context understudy, the recommendations of this study can help developing new mechanisms for Saudi EFL university classrooms. Having discussed the results generated from the current study, the implications of the present study can bring about the following recommendations:

There should be a separate Radio and Television Channel for the teaching of the English language to provide Saudi EFL students with the real authentic source for developing their English language skills.

The government, through the Ministry of Education, should make a clear policy on the integration of media in education to provide an authentic source to the Saudi EFL teachers. Also, Saudi EFL students should also be taught the different ways of learning the language and to make them active learners to exploit the media for the use of AM for language learning. A media campaign should be started with assistance from the state on television and FM Radios about the merits of learning English using sources other than EAP textbooks. Ministry of Education of KSA is working on various projects to regenerate the educational structure of Saudi Arabia. Focusing on this developmental program from the perspective of the English language, it is recommended that Universities should take help from electronic media by establishing viewing centers in different universities to enrich Departments of English. Such a program could also be started in collaboration with the international broadcasting agencies (e.g., British Broadcasting Corporation $\mathrm{BBC}$ ) which has a vast and rich experience of teaching languages using AM through radio and TV programs all over the world.

\section{References}

Adams, T. (1995). What Makes Materials Authentic? (ERIC Document Reproduction Service No. ED 391389).

Abed, G.T. (2003). Unfulfilled Promise: Why the Middle East and North Africa Region has Lagged in Growth and Globalization, Finance and Development. IMF/World Bank, Washington, D.C. pp. 10-17.

Al-Abedalhaq, F. \& Samdi, O. (1996). Spread of English and westernization in Saudi Arabia. World Englishes, 15(3), 307-317.

Al-Mutawa, N., (1994). Factors influencing English language teaching and learning in the secondary schools of Kuwait. Educational Sciences, 1(2), 33-62.

Al-gorashi, A. K. (1988).The English communication needs of military cadets in Saudi Arabia as perceived by junior officers in the Saudi Army and air defense. Unpublished PhD dissertation, Indiana University.

AHarbi, M. (2005). ESP target situation needs analysis: The English language communicative needs as perceived by the health professionals in the Riyadh area. Unpublished $\mathrm{PhD}$ dissertation, Athens: The University of Georgia.

Almulhim, A. M. (2001). An English language needs assessment of Saudi college-of-technology students with respect to a number of business sectors in Saudi Arabia. Mississippi: The University of Mississippi.

Al-Seghayer, K. (2011). English Teaching in Saudi Arabia: Status, Issues, and Challenges. Hala Print Co. Riyadh, Saudi Arabia.

Alatis, H. Altman, \& Alatis, P. (Eds). The second language classroom: Directions for the 1980's (pp. 131-148). New York: Oxford University Press.

Bacon, S., \& Finneman, M. (1990). A study of attitudes, motives, and strategies of university foreign language students and their disposition to authentic oral and written input. The Modern Language Journal, 74(4), 459-473.

Breen, M. (1985). Authenticity in the language classroom. Applied Linguistics, 6, 60-70.

Berardo, S. (2006). The use of authentic materials in the teaching of reading. The Reading Matrix, 6 (2), 60-69.

Bernhardt, E., \& Berkemeyer, V. (1988). Authentic texts and the high school German learner. Teaching German, 21(1), 6-28.

Carney, C., \& Franciulli, M. (1992). The Use of Authentic Reading Materials in the Business Language Classroom. (ERIC Document Reproduction Service No. ED 373538).

Chaves, M. (1998). Learner's perspectives on authenticity. IRAL, 36(4), 277-306.

Cohen, L. \& Manion, L. (1985). Research Methods in Education. London: Croom Helm.

Crookes, G., \& Schmidt, R. W. (1991). Motivation: Reopening the research agenda. Language Learning, 41, 469-512 
Crossley, S., McCarthy, P., Louwerse, M., \& McNamara, D. (2007). A linguistic analysis of simplified and authentic texts. The Modern Language Journal, 91 (1), 15-30.

Day, R.D., \& Bamford, J. (1998). The cult of authenticity and the myth of simplification. In Extensive reading in the second language classroom (pp.53-63). Cambridge: Cambridge University Press.

Day, R. (2008, October). Teaching Foreign Language Reading Fluency. Workshop presented at the 34th JALT International Conference on Language Teaching and Learning and Educational Materials Exhibition, Tokyo.

Duquette, G., Dunnett, S., \& Papalia, A. (1987). The effect of authentic materials in acquiring a second language. Canadian Modern Language Review, 43(4), 479-492.

Elhadi, A.E. (2008). Statistical Analyses for Educational graduated students. Uok, Khartoum, Sudan.

Fanselow, J., \& Crymes, R. (1976). The authenticity of language data. In Explorations in applied Linguistics — $96-$ No. 27 linguistics (pp.159-167). Retrieved September 14, 2006 from www.oup.com/pdf/elf/library=classics/AppLingC12.pdf

Guariento, W., \& Morley, J. (2001). Text and task authenticity in the EFL classroom. ELT Journal, 55 (4), 347 - 353.

Gulzar, M.A. \& Abdulrahman A.A. (2014 a). Effects of Print Media: A Study of Reading Skills among University EFL Students. Research on Humanities and Social Sciences, 4(28),68-79.

Gulzar, M.A. \& Abdulrahman A.A. (2014). Code Switching: Awareness Amongst Teachers and Students in Saudi Universities EFL Classrooms. English Language teaching, 6(2), 1-13.

Gulzar, M.A., Gulnaz, F, Ijaz, A, M (2014) Utility of Krashen's Five Hypotheses in the Saudi Context of Foreign Language Acquisition/Learning. English Language Teaching, 7(8),134-138.

Gulzar, M.A. \& Abdulrahman, A.A. (2013b). Intra-sentential Patterns of Code-mixing between Bilingual Male and Female Teachers: A Comparative Study. Volume 97 No 3, (2013), pp. 411-429, European Journal of Scientific Research.

Gulzar, M.A. \& Abdulrahman. A.A. (2013). Effects of Teacherse Nonverbal Communication on the Learnability of the Adult Saudi EFL Learners: A Case Study. European Journal of Scientific Research, 96(4), 553-571.

http://www.europeanjournalofscientificresearch.com/ISSUES/EJSR_96_4.htm.

Hadley, A. (2001). Teaching language in context (3rd edition). Boston: Thomson Heinle.

Harmer, J. (2001). The practice of English language teaching (3rd edition). London: Longman.

Hedge, T. (2000). Teaching and Learning in the language Classroom. Oxford: Oxford University Press.

Herron, C., \& Seay, I. (1991). The effect of authentic oral texts on student listening comprehension in the foreign language classroom. Foreign Language Annals, 24(6), 487-495.

Hirsh, D., \& Nation, P. (1992). What vocabulary size is needed to read unsimplified texts for pleasure? Reading in a Foreign Language, 8(2), 689-696.

Lee, W. (1995). Authenticity revisited: text authenticity and learner authenticity. ELT Journal, 49(4), 323-328.

Maxim, H. (2002). A study into the feasibility and effects of reading extended authentic discourse in the beginning German language classroom. The Modern Language Journal, 86(1), 20-35.

Miller, M. (2005). Improving aural comprehension skills in EFL, using authentic materials: an experiment with university students in Nigata, Japan. Unpublished master's thesis, University of Surrey, Guildford, UK.

Nostrand, H. (1989). Authentic texts and cultural authenticity: An editorial. The Modern Language Journal, 73(1), 4952.

Otte, J. (2006). Real language to real people: a descriptive and exploratory case study of the outcomes of aural authentic texts on the listening comprehension of adult ESL students enrolled in an advanced ESL listening course. Dissertation Abstracts International, 67 (04), 1246B. (UMI No. 3212979)

Rogers, C., \& Medley, F. (1988). Language with a purpose: Using authentic materials in the foreign language classroom. Foreign Language Annals, 21, 467-478.

Stern, H. (1981). Communicative language teaching and learning: Toward a synthesis. In J.E. Alatis, H. B. Altman, \& P. M. Alatis (Eds.), The Second Language Classroom: Directions for the 1980s (pp. 131-148). New York: Oxford University Press.

Thanajaro, M. (2000). Using authentic materials to develop listening comprehension in the English as a foreign language classroom. Unpublished doctorial dissertation, Virginia Polytechnic Institute and State University, Blacksburg, Virginia.

Ur, P. (1996). A course in language teaching: Practice and theory. Cambridge University Press.

Weyers, J. (1999). The effect of authentic video on communicative competence. The Modern Language Journal, 83(3), 339-349.

Weyers, J. (1999). The effect of authentic video on communicative competence. The Modern Language Journal, 83(3), 339-349.

Young, D. (1999). Linguistic simplification of SL reading material: Effective instructional practice? The Modern Language Journal, 38(3), 350-366. 